\title{
WNT11 wt Allele
}

National Cancer Institute

\section{Source}

National Cancer Institute. WNT11 wt Allele. NCI Thesaurus. Code C52982.

Human WNT11 wild-type allele is located in the vicinity of 11q13.5 and is approximately $20 \mathrm{~kb}$ in length. This allele, which encodes protein wnt-11, is involved in several processes during development. 